\title{
Troche Dosage Form
}

National Cancer Institute

\section{Source}

National Cancer Institute. Troche Dosage Form. NCI Thesaurus. Code C43001.

A solid discoid composed of active and/or inert ing redient(s) in a suitably flavored base, that dissolves when sucked in the mouth. 